\title{
Objeção de consciência na interrupção voluntária da gravidez. Entre a marginalização de profissionais e o retorno do aborto ilegal
}

\section{Conscientious objection in voluntary interruption of pregnancy. Between the marginalization of professionals and the return of illegal abortion}

\section{Objection de conscience en cas d'interruption volontaire de grossesse. Entre la marginalisation des professionnelles et le retour de l'avortement illegal}

Elena Spina ${ }^{1}$

\begin{abstract}
RESUMO: A lei n.194 / 1978, ao legalizar a interrupção voluntária da gravidez (VIP) na Itália, introduziu a cláusula da objeção de consciência e, desde então, muitos ginecologistas têm invocado esse direito (os chamados pró-vida que se opõem ao pró-direito-escolha). A hipótese deste artigo é dupla e diz respeito às conseqüências da objeção de consciência: por um lado, os ginecologistas pró-escolha experimentam uma forma de marginalidade, em termos de carga de trabalho, status social e poder, resultando em seu isolamento e estigmatização; por outro, a dificuldade de acessar serviços VIP pode levar ao retorno do aborto ilegal. O objetivo é imaginar quais as conseqüências que isso pode trazer para os usuários e profissionais e entender como será possível garantir um equilíbrio entre o direito à interrupção voluntária da gravidez e a objeção de consciência. Em termos de metodologia, realizou-se uma revisão de literatura, seguida de uma pesquisa por material documental (jornais e sites italianos e estrangeiros discutindo VIP e objeção de consciência); Além disso, uma longa entrevista foi realizada com um ginecologista pró-escolha, que representa um caso simbólico no contexto italiano. Algumas considerações sobre os cenários futuros fecham o
\end{abstract}

1 Elena Spina é pesquisadora da Polytechnic University of MARCHE, Itália. Email: e.spina@staff.univpm.it 
artigo.

Palavras-chave: Interrupção voluntária da gravidez. Objeção consciente. Aborto ilegal. Serviços de saúde. Divergência intraprofissional.

\begin{abstract}
Law n.194/1978, while legalizing voluntary interruption of pregnancy (VIP) in Italy, introduced the clause of conscientious objection and, since then, many gynaecologists have invoked this right (the so-called pro-life who are opposed to the pro-choice). The hypothesis of this article is twofold and concerns the consequences of conscientious objection: on the one hand, pro-choice gynaecologists experience a form of marginality, in terms of workload, social status and power, resulting in their isolation and stigmatization; on the other, the difficulty of accessing VIP services can lead to the return of illegal abortion. The aim is to imagine what consequences this can bring to both users and professionals and to understand how it will be possible to guarantee a balance between the right to voluntary interruption of pregnancy and that to conscientious objection. In terms of methodology, a literature review, followed by a search for documentary material (Italian and foreign newspapers and websites discussing VIP and conscientious objection) was carried out; moreover, a long interview was conducted with a pro-choice gynaecologist, who represents a symbolic case in the Italian context. Some consideration about the future scenarios close the article.
\end{abstract}

Key words: Voluntary interruption of pregnancy. Conscientious objection. Illegal abortion. Healthcare services. Intra-professional gap.

RESUME: En légalisant l'interruption volontaire de grossesse en Italie, la loi n 194 de 1978 a introduit la clause d'objection de conscience et, depuis lors, de nombreux gynécologues ont invoqué ce droit (les soi-disant pro-vies opposées aux pro-choix). L'hypothèse de cet article est double et concerne les conséquences de l'objection de conscience : d'un côté, les gynécologues pro-choix subissent une forme de marginalité, en termes de charge de travail, de statut social et de pouvoir, ce qui entraîne leur isolement et leur stigmatisation; d'autre côté, la difficulté d'accéder aux services liés à l'interruption volontaire de grossesse peut entraîner le retour d'un avortement illégal. L'objectif est d'imaginer les conséquences que cela peut avoir pour les utilisatrices et les professionnels et de comprendre comment il sera possible de garantir un équilibre entre le droit à une interruption volontaire de grossesse et celui à l'objection de conscience. Sur le plan méthodologique, une revue de la littérature, suivie d'une recherche de documents (journaux italiens et étrangers et sites Web traitant de l'interruption volontaire de grossesse et de l'objection de conscience) a été réalisée; de plus, un long entretien a été mené avec un gynécologue prochoix, qui représente un cas symbolique dans le contexte italien. Quelques considérations sur les scénarios futurs ferment l'article.

Mots-cles: Interruption volontaire de grossesse. Objection de conscience. Avortement illégal. Services de santé. Divergence intra-professionnelle. 


\section{INTRODUCTION}

In 1978, following an advisory referendum, Law n.194/78 entitled "Rules for the social protection of motherhood and voluntary interruption of pregnancy" was passed. Its aim was to regulate the use of abortions, to eliminate clandestine abortions and to regulate the procedures governing the voluntary interruption of pregnancy (VIP).

Before the approval of law no.194 motherhood field was regulated by the Rocco Code and the only form of abortion allowed was therapeutic abortion, that is the interruption of pregnancy carried out to save the life of the mother. In any other case abortion was considered a crime. The interruption of pregnancy, in fact, was considered not as a crime against the person, but against the State, as an attack on the "lineage"

Article 9 of the law no.194 introduced the clause of conscientious objection by stating that "physicians, nurses and other personnel are not held to take part in the procedures of articles 5 and 7 as well as the operation for interruption of pregnancy, if they raise conscientious objection, through a previous general declaration to that effect."

Since its introduction, many professionals (especially gynaecologists, but also anaesthetists, nurses and midwives) have invoked their right to conscientious objection.

On the one hand, this clause represents an obstacle to the effective exercise of a woman's right to interrupt a pregnancy; on the other, it can act as an element of intra-professional gap that produces and realizes forms of marginality, linked with the gap between different sets of values (Fiala and Arthur, 2014).

After briefly presenting recent data on conscientious objection in Italy, on the one hand the article illustrates the recent problems due to the absence of pro-choice doctors and, in the other hand, it focuses on the rift within gynaecology. Some consideration about the future scenarios close the article.

\section{VOLUNTARY INTERRUPTION OF PREGNANCY AND THE CONSCIENTIOUS OBJECTION IN ITALY: A SNAPSHOT}

Conscientious objection is an option available in both Italy and other European countries where abortion laws were liberalized from the 1960s onwards (Chavkin et al., 2017). However, it is still largely unregulated across Europe, and abuses therefore appear to be systemic (Center for Reproductive Rights, 2010).

In the European scenario, Italy stands out due to its high percentage of objectors, which has no parallel in other countries, such as England, where only 10\% of doctors invoke a similar clause (Green, 1995; Momigliano 2016). Moreover, in Italy the Roman Catholic Church exerts a very 
strong influence at the political level through deep-rooted Catholic lobbies that guide decisions and choices (Carcano, 2016; Pinotti, 2010; Oliva, 2010; Portanova, 2009). Since the law came into force in Italy, the number of objectors has grown exponentially, involving gynaecologists, anaesthetists and other health professionals (nurses and midwives).

Over the past decade, the number of gynaecologists who invoke conscientious objection has increased from $58 \%$ to $70.9 \%$ (Ministry of Health, 2017). Considerable variation among regions can be observed: in some areas of the country (such as Lazio and Sicily), more than $90 \%$ of all gynaecologists ${ }^{2}$ are pro-life, jeopardizing the chances of women to exercise their right to terminate a pregnancy (Quotidianosanità.it, 2014).

Estimates and calculations made by Ministry of Health and based on precise parameters ${ }^{3}$ deny the existence of a problem. However, according to Cirant (2012), the average figures calculated by the Ministry to assess the congruity between available and necessary resources ignore the epidemiological indications of how such calculations should operate at the local level. Therefore, ministerial estimates do not consider peripheral contexts in which there is unlikely to be congruity, so that about $40 \%$ of the Italian hospitals have not a VIP service.

This critical issue has pushed some organizations (such as the International Planned Parenthood Federation European Network and the Italian General Confederation of Labor) to draw attention to a state of emergency, exacerbated by the shortage of younger colleagues to replace retiring prochoice gynaecologists. ${ }^{4}$

In its 2017 report, the Human Rights Committee of the United Nations alleges the high percentage of doctors who refuse to perform abortions has resulted in "a significant number of clandestine abortions being carried out," though it fails to provide further information or statistics to back up its claim. The United Nations calls on Italy to "take measures necessary to guarantee unimpeded and timely access to legal abortion services in its territory, including by establishing an effective referral system for women seeking legal abortion services (Human Right Committee, 2017).

\footnotetext{
2 The term pro-life gynaecologists is used here to define doctors who invoke conscientious objection; on the contrary, their colleagues who practice abortion are called pro-choice gynaecologists.

3 In order to determine the extent of the phenomenon, the Ministry has for many years used three parameters that show supply according to both the demand and the availability of instrumental and professional resources:

1. The supply of the VIP service in relation to the total number of available facilities;

2. The supply of the VIP service in relation to the female population of childbearing age and birth locations;

3. The supply of the service in relation to professionals' right to conscientious objection, calculated on the basis of the average weekly VIP workload for each non-objector gynaecologist.

4 In 2012, the International Planned Parenthood Federation European Network filed a complaint against Italy to the European Committee of Social Rights, claiming that the country's high number of conscientious objectors in the medical field resulted in inadequate protection of the right to access abortion and therefore a violation of the right to health.
}

Tempus, actas de saúde colet, Brasília, 13(2), 205-216, jun, 2019. ISSN 1982-8829 


\section{THE RESEARCH DESIGN}

The hypothesis underlying this work are two, both based on the consequences produced by conscientious objection:

1. on the one side, it reduces and limits the use of VIP services, contributing to the return of clandestine abortion;

2. on the other, it produces an intra-professional rift ending up pro-choice gynaecologists in a marginal position.

Given these hypotheses, the aim of the article is to imagine what consequences this can bring to both users and professionals. Furthermore, it would be important to understand how it will be possible to guarantee a balance between the right to voluntary interruption of pregnancy and that to conscientious objection, especially in a conservative thought like the one currently present in Italy.

In terms of methodology, a literature review, followed by a search for documentary material (Italian and foreign newspapers and websites discussing VIP and conscientious objection) was carried out. This led to the identification of a recent autobiographical publication by a pro-choice gynaecologist, who represents a symbolic case in the Italian scenario. A long interview was conducted with him, during which he was invited to further reflect on conscientious objection.

\section{THE CONSCIENTIOUS OBJECTION AND THE RETURN OF CLANDESTINE ABORTION}

That the conscientious objection limits the use of services is more than a hypothesis: 40 years after its approval the law is still far from the effective application. This brings back the specter of illegal abortions.

There are no reliable data on this issue because there is no monitoring; the number of abortion requests is unknown because the data is not recorded after all. Ministerial data on abortions are transmitted by doctors who perform VIP after filling out a data sheet. When, for instance, the only pro-choice gynecologist who work in a hospital retires, the sending of the forms and therefore the monitoring ceases. Obviously, the VIP request does not cease but it is not recorded.

Illegal abortions are estimated at between 12,000 and 15,000 in the case of Italian women, and between 3,000 and 5,000 for immigrants. Moreover, according to data from the Ministry of Health, there has been a drastic reduction in VIP over the years and, on the other hand, the number of spontaneous abortions has increased ( $+31.4 \%$ since 1982). Comparing these data, the suspicion is that the reduction in the former is strictly linked to the increase in the latter; therefore, spontaneous abortions could be the result of clandestine abortions.

ISSN 1982-8829 Tempus, actas de saúde colet, Brasília, 13(2), 205-216, jun, 2019. 
Apart from these number, the stories of women show a different situation than that documented by the official data.

Silvana Agatone, president of LAIGA, argues that abortions that escape statistics can be divided into three types. The first is the so called "gold abortions": these are interruptions requested by women belonging to medium-high social classes and operated in private clinics where they are recorded as other types of intervention rather than VIP. The second type is the clandestine abortions performed by women who do not find places in the public hospitals and are forced to find other solutions, including the "do it yourself" solution (perhaps assuming drugs that, having high doses, can be very dangerous for health). These solutions are increasingly accessible thanks to the web (that can be call a "2.0 backstreet abortionist") where there are over 35,000 e-pharmacies, of which $95 \%$ are illegal.

The third type concerns the most fragile women, especially immigrants (often irregular), who ignore their rights and therefore do not know what the law foresees. Recent is the case of "Doctor Friday", a Nigerian man who solved the problem of unwanted pregnancies by administering drugs and practicing violent manual maneuvers.

Two other aspects seem to aggravate an already problematic situation. The first concerns the closure of family planning clinic and the unification of maternity units (together with their departments of gynecology and obstetrics), which makes the interruption of pregnancy a real obstacle course. The second one, concerns the pharmacists' reluctance to sell the 5-day pill even though in Italy it can be sold without a prescription and without having to undergo the pregnancy test.

A further complication is linked to the prevailing mode of practicing VIP which, in Italy, remains the surgical one, despite the pharmacological solution which is rather limited $(15 \%$ against $98 \%$ in Finland, 90\% in Sweden, $65 \%$ of Portugal, $60 \%$ of England and $57 \%$ of France). Since December 2009 the abortion pill (Ru-486) can be used in Italy. Although 10 years have passed since the approval of this technique, definitely less invasive than the surgical one, there are still few hospitals where the interruption of pregnancy is carried out in this way.

What appears evident, in this context, is that conscientious objection, practiced by such high numbers of professionals, can make access to services difficult, slowing down the regular progress of interventions and, ultimately, fueling the use of illegal abortion.

\section{CONSCIENTIOUS OBJECTION AS INTRA-PROFESSIONAL GAP}

The second hypothesis is that conscientious objection generates an intra-professional rift, therefore pitting pro-choice gynecologists and pro-life ones. 
The interview confirms the existence of a gap within the profession. According to the witness interviewed for this study, this gap dates to his university years, when the debate on VIP was intensive and the law was about to be passed. At that time, however, the conflict was based on the ideological positions of students who had not yet started clinical practice.

Therefore, if before starting their medical careers, most doctors were in favour of the legislation that legalized abortion, things later changed and many them invoked the objection clause. However, the gap remained and, indeed, in some ways the conflict became harsher. Several factors exacerbate it, two of which appear particularly significant.

The first refers to the difficulty of reconciling, at least at an ethical level, the choice to object with the need to carry out antenatal screening, which represents a "hypocritical fact. Either you are prochoice, or you do not prescribe prenatal diagnosis. Because if so you're a sadist".

The second factor concerns the absence of an official position on the objection clause from professional representative bodies that "have removed it ... [...] they always support women but a clear position, a specific space dedicated to this issue, no, there isn't'

This gap produces isolation putting pro-choice doctors in a marginal position. This marginality can be defined:

- $\quad$ in terms of workload: as a result of their small numbers, pro-choice gynaecologists may experience long shifts and a demanding work schedule (Calzavara, 2016; De Zordo, 2015);

- $\quad$ in terms of social status, doctors who practice interruption of pregnancy are often stigmatized by both their colleagues and wider society (O'Donnell et al., 2011; Harris et al., 2011; Joffe, 1995; Wicklund and Kesselheim, 2007; Freedman et al., 2010; Norris et al., 2011; Cowan, 2017);

- $\quad$ in terms of power, the choice about whether to invoke the objection clause can have consequences in term of career paths (incentives vs penalties) (De Zordo, 2015; Momigliano, 2016).

In terms of workload, from the story told by the key informant, it is clear that being an abortionist is hard work "because the service falls on you..." In the most extreme cases, the workload of prochoice doctors can be so heavy that it leads them to object to it on health grounds (Momigliano, 2016). Moreover, being pro-choice often means, on the one hand, giving up important career opportunities since the workload in the hospital can limit the implementation of private practice (Momigliano, 2016). On the other, it means having fewer opportunities for professional growth since less time is available for other types of interventions that are also included in professional practice, as explained by the president of the main association of pro-choice gynaecologists (LAIGA). 


\section{$212 / /$}

In terms of power, specifically in terms of career progression, the interview openly highlights the discrimination experienced by pro-choice professionals: "Being an abortionist is a heavy work, for the type of job, for the type of career block this can produce. Nobody who is pro-choice has ever become a chief doctor here. Here gynaecologists are all objectors."

Therefore, discrimination exists or, at least, is perceived to do so. In this regard, the influence exerted by the Catholic lobby (Carcano, 2016; De Zordo, 2015) appears to be fundamental. This is widely documented in the literature, in which recruitment and promotion policies emerge as a mechanism used to favour pro-life careers (Momigliano, 2016).

Moreover, a socialization process towards conscientious objection appears to emerge. Since university training (and afterwards, during the first years of professional practice), an environment of encouraging the choice to object appears to prevail (Lazarus, 1997). On the one hand, as explained by the gynaecologist interviewed by the newspaper, while talking about her professional experience in a Roman hospital, "Students were forbidden to attend VIP, and those who insisted were reprimanded. Therefore, they understand how things stand. Then, only pro-life doctors were hired" (Momigliano, 2016).

Furthermore, the existence of abuse by objectors can be decisive. This situation occurs when auxiliary staff (anaesthetists, nurses and midwives) refuse to collaborate in activities not directly linked to the procedure, leaving the doctor in complete isolation to do his or her job in very difficult conditions (Fiala and Arthur, 2014; Cook and Dickens, 2006; Dickens, 2006, 2008, 2009) .

Even status, the social consideration of which is a fundamental component enjoyed by prochoice gynaecologists, seems to place pro-choice gynaecologists in a marginal position.

Goffman (1963, p.3) first described stigma as an "attribute that is deeply discrediting" and noted that stigma transforms people from "whole and usual" individuals to "tainted", discounted ones in the minds of those around them (Harris et al., 2011). Furthermore, Hughes (1956, 1958, 1971 pp.338-347) referred to stigmatized work "dirty work" and its practitioners as "dirty workers". These workers perform socially necessary functions that are tainted by physically disgusting, socially degrading or morally dubious elements. They risk adverse psychosocial consequences, including the loss of status, discrimination and disclosure difficulties (Harris et al., 2011).

As he points out in his book the non-objection choice "produces isolation, forces one towards an Indian reservation of neglected people and implies labels like Herod.

\section{SOME CONSIDERATIONS}

Over 40 years after the promulgation of law No.194, the situation seems to be paradoxical. On the one hand the right to VIP exists and is protected by law; on the other, the access to service is limited by the massive presence of pro-life professionals, since, at the same time, conscientious Tempus, actas de saúde colet, Brasília, 13(2), 205-216, jun, 2019. ISSN 1982-8829 
objection is guaranteed by the law. This affects both access to women's services and professional cohesion, as pro-choice are marginalized and isolated, working in very hard and conditions.

On the background there is a disoriented public opinion, polarized on pro-life and pro-choice positions, which are followed by activist movements (Orciani et al. 2018). In this framework, the conservative atmosphere which has been established recently in Italy, seems to exacerbate the situation, considering that it seems to call into questions some principles appear to be established.

It is not easy to understand how to get out of this impasse. however, there may be some viable ways.

One way may be to limit the number of pro-life professionals within healthcare services. As has already happened in the spring of 2016 in a large Roman hospital, competitions could be reserved for pro-choice professionals. In this way the balance between the number of pro-life and pro-choice could be reached and VIP service guaranteed. This would encourage young professionals not to make a convenient objection (as unfortunately happens to avoid marginality and stigma). Here, however, a problem arises linked to the scarce socialization of the young professionals during training with respect to the abortive practice: since university training (and afterwards, during the first years of professional practice), an environment of encouraging the choice to object appears to prevail (Lazarus, 1997). On the one hand, Students are often forbidden to attend VIP, and those who insisted were reprimanded. Therefore, they understand how things stand. Then, only pro-life doctors are hired (Momigliano, 2016).

What is sure is that as long as this situation do not break the impasse many women will remain in the quagmire, disoriented with respect to the choices to be made and the concrete ways of carrying out them.

\section{REFERENCES}

1. Calzavara V, Solo 3 medici non obiettori con cento casi ciascuno. La tribuna di Treviso, 2016, 12 April 2016, https://www.cislveneto.it/Rassegna-stampa-Veneto/Solo-3-medici-nonobiettori-con-cento-casi-ciascuno, Accessed Date: 15 February 2018.

2. Carcano R, La scelta di vita di chi pensa di averne una sola. 2016, Nessun Dogma, Roma.

3. Center for Reproductive Rights, Abortion opponents undercut council of Europe resolution on conscientious objection, 2010 http://reproductiverights.org/en/press-room/abortion-opponentsundercut-council-of-europe-resolution-on-conscientious-objection, Accessed Date: 15 February 2018.

4. Chavkin W, Swerdlow L, Fifield J, Regulation of Conscientious Objection to Abortion. An International Comparative Multiple-Case Study. 2017, Health Hum. Rights 19 (1): 55-68.

ISSN 1982-8829 Tempus, actas de saúde colet, Brasília, 13(2), 205-216, jun, 2019. 
5. Cirant E, Una su cinque non lo fa. Maternità e altre scelte. 2012, Franco Angeli, Milano.

6. Cook, R., Dickens, B., 2006. The growing abuse of conscientious objection. Virtual Mentor, 8, 337-340. http://virtualmentor.ama-assn. org/2006/05/pdf/oped1-0605.pdf, Accessed Date: 1 February 2018.

7. Cowan SK, Enacted abortion stigma in the United States. 2017, Soc. Sci. Med. 177(3): 259268.

8. De Zordo S, I veri motivi dell'obiezione di coscienza sull'aborto. 2015, https:// abortoinchiesta.wordpress.com/2015/05/23/obiezione-coscienza-aborto-ricerca-antropologica/, Accessed Date: 1 February 2018.

9. Dickens MB, Ethical misconduct by abuse of conscientious objection laws. $2006 \mathrm{Med}$. Law. 25 (3): 513-522.

10. Dickens MB, The art of medicine: conscientious commitment. 2008, Lancet, 371 (April): 1240-1241. http://www.thelancet.com/pdfs/journals/lancet/PIIS0140-6736(08)60547-4.pdf, Accessed Date: 18 Genuary 2018.

11. Dickens MB, Unethical protection of conscience: defending the powerful against the weak. 2009, Virtual Mentor, 11 (9): 725-729. http://virtualmentor.ama-assn.org/2009/09/oped20909.html, Accessed Date: 1 February 2018.

12. Fiala A, "Dishonourable disobedience" - Why refusal to treat in reproductive healthcare is not conscientious objection. 2014, Woman Psychosomatic Gyn. Obs. 1: 12-23.

13. Freedman L, Landy U, Darney P, Steinauer J, Obstacles to the integration of abortion into obstetrics and gynecology practice. 2010, Perspect. Sex. Repro. H. 42 (3): 146-151.

14. Goffman E, Stigma: Notes on the management of spoiled identity. 1963, Prentice Hall, New York.

15. Green JM, Obstetricians' views on prenatal diagnosis and termination of pregnancy: 1980 compared with 1993. 1995, Brit. J. Obstet. Gynaec. 102: 228-232.

16. Harris LH, Debbink M, Martin L, Hassinger J, Dynamics of stigma in abortion work: findings from a pilot study of the Providers Share Workshop. 2011, Soc. Sci. Med. 73 (7): 10621070.

17. Hughes EC, Social role and the division of labor. 1956, Midw. Soc. 18 (2): 3-7.

18. Hughes, EC, Men and their work. 1958, Gree Press, Glencoe, Illinois.

Tempus, actas de saúde colet, Brasília, 13(2), 205-216, jun, 2019. ISSN 1982-8829 
19. Hughes EC, Work and self. The sociological eye: Selected paper. 1971, Transaction Publishers, New Brunswick.

20. Human Rights Committee (HRC), United Nations, Concluding observations on the sixth periodic report of Italy, 1 May 2017, CCPR/C/ITA/CO/6, 2017, available at: http://www.refworld. org/docid/591e9a6b4.html, Accessed Date: 15 February 2018.

21. Joffe C, Doctors of conscience: The struggle to provide abortions before and after Roe v. Wade. 1995, Beacon Press, Boston.

22. Lazarus ES, Politicizing abortion: Personal morality and professional responsability of residents training in the United States. 1997, Soc. Sci. Med. 44(9): 1417-1425.

23. Ministry of Health, Relazione del Ministro della salute sulla attuazione della legge contenente norme per la tutela sociale della maternità e per l'interruzione volontaria di gravidanza (legge 194/78). 2017, Decembre 2017. http://www.salute.gov.it/imgs/C_17_pubblicazioni_2686_ allegato.pdf, Accesed Date: 18 Genuary 2018.

24. Momigliano A, L'obiezione è davvero una questione di coscienza? 2016, http://www. rivistastudio.com/standard/aborto-medici-obiettori-di-coscienza/, Accessed Date: 1 February 2018 .

25. Norris A, Bessett D, Steinberg JR, Kavanaugh ML, Zordo SD, Becker D, Abortion stigma: A reconceptualization of constituents, causes and consequences. 2011, Women Health Iss. 21 (Suppl. 3): 49-54.

26. O’Donnell J, Weitz TA, Freedman LR, Resistance and vulnerability to stigmatization in abortion work. 2011, Soc. Sci. Med. 73 (9): 1357-1364.

27. Oliva M, Il sistema di potere di Comunione e liberazione, 2010, Il Fatto Quotidiano, 22 August 2010, https://www.ilfattoquotidiano.it/2010/08/22/il-sistema-di-potere-di-comunione-eliberazione/51990/,Accessed Date: 15 February 2018.

28. Orciani B, Radin A, Spina E, Naissance et objection de conscience : les raisons des professionnels, in Ferreol G. (edd) Système de santé et politiques de soins : vers de nouveaux défis ?, 2018 EME Editions, Louvain-la-Neuve.

29. Pasqualetto A, Segato M, L'ho fatto per le donne. Confessioni di un ginecologo non obiettore. 2017, Edizioni Mondadori, Milano.

30. Pinotti F, La lobby di Dio. Fede, affari e politica. La prima inchiesta su Comunione e 
Liberazione e la Compagnia delle opere. 2010, Chiarelettere. Milano.

31. Portanova M, Commistione e lottizzazione. 2009, Altreconomia, 25 August 2009, https:// altreconomia.it/commistione-e-lottizzazione/, Accessed Date: 15 February 2018.

32. Quotidianosanità.it, Ivg. La Laiga denuncia: "Aumento degli obiettori di coscienza blocca l'applicazione della 194". 2014, http://www.quotidianosanita.it/lavoro-e-professioni/articolo. php?articolo id=24713, Accessed Date: 15 February 2018.

33. Wicklund S, Kesselheim A, This Common Secret: My Journey as an Abortion Doctor. 2007, PublicAffairs, New York.

Artigo apresentado em: março 2019

Artigo aprovado em: abril 2019 Conflito de interesses: a autora declara não haver conflito de interesses Suporte financeiro: não 